\title{
APLICAÇÃO DA TÓPICA JURÍDICA NO DIREITO AMBIENTAL: Análise de um Caso Concreto do Estado de Minas Gerais
}

\section{Bruno Malta Pinto}

Mestre em Direito pela UFMG. brunomalta@ymail.com

\section{Resumo}

0 presente artigo pretende, a partir de um caso prático vivenciado em um procedimento administrativo de licenciamento ambiental no Estado de Minas Gerais, ilustrar a aplicação da tópica concretista, em especial a desenvolvida por Friedrich Müller, avaliando seus elementos e a desenvoltura da metódica para a decisão em concreto de dada situação-problema.

A tópica de viés concretista, inspirada na tópica "pura" resgatada no âmbito jurídico por Theodor Viehweg (1907-1988), surge como um dos modelos de superação do positivismo legalista.

Os balizamentos para a interpretação e os elementos de trabalho de que se vale a tópica concretista ofertam para a Teoria do Direito um modelo de superação do paradigma estabelecido pelo positivismo, centrado não mais apenas no teor literal de determinada prescrição normativa, mas em todo um aporte de elementos hábeis à construção de uma decisão voltada para o caso concreto.

Após a apresentação do caso prático com a delimitação do problema, proceder-se-á a uma breve análise da tópica, com ênfase em Viehweg e Müller, para, então, buscar-se uma solução individualizada ao caso concreto analisado com os recursos emprestados pela tópica concretista desse último autor, concluindo-se que a tópica, encarada como técnica de pensar problemático, conduz a uma decisão jurídica não apenas formalmente correta, mas materialmente adequada, a partir da análise do caso concreto.

\section{Palavras-chave}

Tópica Concretista. Aplicação prática. Direito Ambiental. 


\section{LEGAL TOPIC APPLICATION IN ENVIRONMENTAL LAW: ANALYSIS OF A CASE OF THE STATE OF MINAS GERAIS}

\section{Abstract}

This article aims, from a practical case in an administrative procedure of environmental licensing in the state of Minas Gerais, to illustrate the application of concretist topic, especially developed by Friedrich Müller, evaluating its elements and the resourcefulness of methodical in solving concretely a specific problem situation.

The concretist topic, inspired by the "pure" topic brought back on the legal framework by Theodor Viehweg (1907-1988), emerges as one of the models for overcoming the legalistic positivism.

The concretist topic proffers the legal theory, trough the reference point for the interpretation and its working elements, a model to overcome the paradigm established by positivism, focusing not only on the wording of certain normative prescription, but throughout a contribution of skillful elements to the building of a decision focused on the case.

After the presentation of the practical case with the delimitation of the problem, we will proceed to a brief analysis of the topic, emphasiziyng on Viehweg and Müller, so then look up an individualized solution to the case analyzed with resources borrowed by concretista topic from the latter author, concluding that topic, seen as problematic technique of thinking, leads to a legal decision not only formally correct, but materially adequate.

\section{Keywords}

Concretist topic. Practical application. Environmental Law.

\section{Sumário}

1 Breve Contexto Acerca da Proteção Ambiental. 20 Caso Prático e seus Contornos. 2.1 Considerações sobre o Ato Normativo Estadual. 3 A (Im)Possibilidade de Superação da Questão pelo Paradigma do Positivismo. 4 A Tópica e o seu Desenvolvimento. 4.1 A Tópica em Viehweg. 4.2 A Tópica em Müller. 5 A Tópica e o Caso Concreto. 6 Conclusão. 7 Referências. 


\section{BREVE CONTEXTO ACERCA DA PROTEÇÃO AMBIENTAL}

O meio ambiente mereceu proteção especial no artigo 225 da Constituição da República Federativa do Brasil de 1988 - CRFB 88 - (Brasil, 1988). Afirma-se ali o meio ambiente ecologicamente equilibrado enquanto direito de todos, encontrando referido direito, na sadia qualidade de vida, o seu conteúdo essencial.

Antes, porém, e sem que se faça uma longa viagem no tempo, já a Lei Federal n. 6.938, de 31 de agosto de 1981 (Brasil, 1981), hoje recepcionada pelo novo ordenamento constitucional, instituiu a Política Nacional do Meio Ambiente (PNMA), dispondo expressamente acerca de seus fins e mecanismos de formulação e aplicação.

O referido diploma normativo apresenta, logo em seu artigo $3^{\circ}$, I e V, as definiçôes de meio ambiente e recursos ambientais:

Art. $3^{\circ}$ Para os fins previstos nesta Lei, entende-se por:

I - meio ambiente, o conjunto de condições, leis, influências e interações de ordem física, química e biológica, que permite, abriga e rege a vida em todas as suas formas;

$[\ldots]$

$\mathrm{V}$ - recursos ambientais: a atmosfera, as águas interiores, superficiais e subterrâneas, os estuários, o mar territorial, o solo, o subsolo, os elementos da biosfera, a fauna e a flora.

A partir dessas definiçôes, estabeleceu-se no artigo $9^{\circ}$, IV, como um dos instrumentos da PNMA, o "licenciamento e a revisão de atividades efetiva ou potencialmente poluidoras", afirmando-se a necessidade de licenciamento para toda atividade utilizadora de recursos ambientais, consoante o disposto na regra do artigo 10, segundo o qual:

A construção, instalação, ampliação e funcionamento de estabelecimentos e atividades utilizadores de recursos ambientais, efetiva ou potencialmente poluidores ou capazes, sob qualquer forma, de causar degradação ambiental dependerão de prévio licenciamento ambiental. 
O licenciamento ambiental, portanto, aparece como instrumento da PNMA que, em interface com o novo ordenamento constitucional, viabiliza a utilizaçáo dos recursos ambientais de forma sustentável, buscando-se a compatibilização entre a garantia de um meio ambiente ecologicamente equilibrado e a atividade econômica, eixo de pensamento sobre o qual se assenta a ideia de desenvolvimento sustentável.

O relatório Our Commom Future, também conhecido como relatório Brundtland, em referência à primeira-ministra norueguesa, Gro Harlem Brundtland, publicado em 1987 pela Comissão Mundial sobre Meio Ambiente e Desenvolvimento da ONU, define o desenvolvimento sustentável como "o desenvolvimento que satisfaz as necessidades presentes, sem comprometer a capacidade das geraçôes futuras de suprir suas próprias necessidades.”

A possibilidade real de estabelecimento do desenvolvimento sustentável parece, então, ganhar contornos de nitidez, afastando-se de mero postulado ou conceito indeterminado, quando se busca a compatibilizaçáo entre a necessidade de preservação ambiental e o imperativo de desenvolvimento econômico por meio do licenciamento ambiental.

É necessário e imprescindível, portanto, delimitar bem o âmbito de proteção do direito ao meio ambiente ecologicamente equilibrado, enquanto direito fundamental, para que se consiga determinar até que ponto outras alternativas convirjam para aquele equilíbrio sem descurar do também fundamental direito ao desenvolvimento econômico.

Ao tratar da dimensão do direito fundamental ao meio ambiente ecologicamente equilibrado, Ney de Barros Bello Filho alerta que:

Se a positivação constitucional do ambiente significar apenas uma norma programática ineficaz, uma norma endereçada ao legislador, ou um valor que não implica obrigação ou dever, não haverá qualquer modificação significativa decorrente da existência de um direito fundamental ao ambiente, e de um direito ambiental das mudanças climáticas (2012, p. 18).

Preocupação de igual teor é vista por Germana Belchior, quando assinala: 
A Constituição de 1988 se torna "esverdeada" ao adotar uma concepção holística e autônoma de meio ambiente, distanciando-se totalmente dos modelos anteriores. [...] O grande e verdadeiro problema é a falta de efetividade das normas ambientais, ou seja, da sua aplicação real mudando os fatos sociais (2011, p. 64-65).

É preciso que se busque uma superação dos antigos paradigmas norteadores da atuação jurídica tão comumente propalados e irrefletidamente absorvidos na prática jurídica brasileira. A efetividade ou concreção dos direitos com assento constitucional, sobretudo aqueles considerados fundamentais, como é o caso do direito ao meio ambiente ecologicamente equilibrado, exigem uma leitura que ultrapasse o (mau) hábito corrente na práxis de enxergar a Constituição sob a lente de uma teoria formal, fortemente atrelada ao positivismo jurídico, que ainda enxerga os direitos constitucionais dentro de esquemas de lógica formal, aguardando a realização dos fatos jurídicos para concatenar uma operação silogística de aplicação da premissa maior constitucional.

Paulo Bonavides assinala os efeitos que de uma tal concepção de Direito se extraem e que, náo raro, ditam a forma como o Direito tem sido sentido e experimentado no Brasil:

Ninguém à primeira vista parece defender tanto a juridicidade das Constituiçóes quanto os positivistas formais. E o fazem naturalmente a contento, enquanto o texto escrito não se arreda muito da realidade. Mas quando esta já não se deixa captar pelas regras do direito positivo formal principia a crise, isto é, a perplexidade diante do divórcio entre a norma e o fato, levantando-se de imediato o problema da mudança constitucional (2004, p. 173).

A tópica e as teses formuladas por Friedrich Müller parecem confluir no sentido de superação de entraves como os ora mencionados por Bonavides e que são vistos cotidianamente na prática dos tribunais e dos órgãos da Administração Pública.

Sem aderir expressamente à tópica, Bello Filho caminha em conclusão semelhante à tal proposta, quando numa primeira conclusão afirma: 
A consequência natural de um direito fundamental ao ambiente sadio e ecologicamente equilibrado é que ele possa ser tutelado mediante decisóes judiciais as quais se socorrem os particulares e a sociedade civil em busca da concretização do seu direito, com a consequente redução da prática de atos que contribuam para as mudanças climáticas (2012, p. 27).

Como será observado adiante, a tópica permite a aproximação do caso concreto, ensejando uma decisão mais justa e equânime e não, exclusivamente, uma decisão formalmente correta, mas, sobretudo, materialmente adequada.

Tomando-se, então, como pano de fundo o cenário constitucional e as diretrizes estabelecidas para a defesa e preservação do meio ambiente, assim como as diretrizes asseguradoras da ordem econômica, delimitar-se-á, em seguida, a situação-problema.

\section{CASO PRÁTICO E SEUS CONTORNOS}

No âmbito do Estado de Minas Gerais e dentro de sua perspectiva autonômica de erigir mecanismos de controle e preservação ambiental, em conformidade com o Sistema Nacional de Meio Ambiente (Sisnama), estabelecido pela PNMA, o licenciamento ambiental exsurge como um desses instrumentos, ao lado de outros que, igualmente, têm por objeto a utilização de recursos ambientais.

No microcosmo do Sistema Estadual de Meio Ambiente (Sisema), ao lado de outros órgãos e entidades responsáveis pela guarida do bem ambiental, compete à Secretaria Estadual de Meio Ambiente e Desenvolvimento Sustentável (Semad), dentre outras atribuiçóes:

[...] formular, coordenar, executar e supervisionar as políticas públicas para conservaçáo, preservaçáo e recuperaçáo dos recursos ambientais, visando ao desenvolvimento sustentável e à melhoria da qualidade ambiental do Estado [...] (art. 4º, caput, da Lei estadual n. 21.972, de 21 de janeiro de 2016).

Ainda nesse contexto, as Superintendências Regionais de Meio Ambiente aparecem como braços executivos da Semad, competindo-lhes, ao seu turno e nos limites de sua abrangência territorial, analisar de forma integrada e interdisciplinar, 
atuando por delegação do Conselho Estadual de Política Ambiental (Copam), no licenciamento de fonte ou atividade poluidora ou degradadora do meio ambiente, sugerindo o deferimento ou indeferimento de licenças ambientais (artigo 38, IV e VI, do Decreto estadual n. 45.824, de 20 de dezembro de 2011).

O caso prático colocado como situação-problema neste estudo foi levado ao conhecimento e analisado por uma das Superintendências Regionais da Semad.

Visando à expansão da atividade de lavra de uma jazida de calcário, determinada sociedade empresária alegou ser necessário suprimir dez indivíduos arbóreos da espécie Dimorphandra Wilsonii Rizz, vulgarmente conhecida como Faveiro de Wilson, no curso do procedimento de licenciamento da ampliação da atividade que se pretendia desenvolver.

Em razão da rigidez locacional, a indicar a inexistência ou impossibilidade de eleição de local diverso para a efetivação ou operação das atividades mineradoras, a ampliação que se pretendia naquele procedimento administrativo deveria necessariamente seguir o projeto apresentado nos estudos ambientais e, consequentemente, avançar em direção aos indivíduos arbóreos.

Um decreto editado pelo chefe do Executivo estadual, entretanto, impedia, em tese, o prosseguimento do mencionado licenciamento ambiental e a supressão dos Faveiros de Wilson, porque declarava a espécie como imune de corte e exploração no Estado.

Diante da impossibilidade erigida pelo instrumento normativo estadual, a sociedade empresária, interessada na supressão dos indivíduos arbóreos, desenvolveu um projeto de conservação e manejo da espécie em parceria com a Fundação Zoobotânica Municipal de Belo Horizonte.

Nesse projeto pode-se atestar a curta expectativa de vida dos dez indivíduos que se pretendia suprimir, determinando-se o manejo adequado à espécie a partir de análises de solo e de sua variabilidade genética, inclusive quanto às possibilidades de êxito no salvamento dos indivíduos. 
Os estudos apresentados nos autos do licenciamento ainda indicavam que os dez indivíduos não compunham um fragmento florestal, encontrando-se, portanto, isolados, o que reduzia as expectativas de sobrevida da espécie naquele local, além de indicar que os mesmos não desempenhavam qualquer função ambientalmente relevante.

Todas as medidas adotadas pela sociedade empresária objetivavam, em um primeiro plano, a criação de condiçóes para a perpetuação da espécie ameaçada a fim de que, em um segundo momento, fosse superada a literalidade de um dispositivo do instrumento normativo estadual, permitindo-se ao Copam deliberar sobre o licenciamento ambiental com vistas ao seu deferimento.

\subsection{Considerações sobre o ato normativo estadual}

$\mathrm{O}$ ato do governador impeditivo da continuidade das atividades mineradoras é o Decreto Estadual n. 43.904, de 26 de outubro de 2004, transcrito a seguir na íntegra:

O GOVERNADOR DO ESTADO DE MINAS GERAIS, no uso de atribuição que lhe confere o inciso VII do art. 90 da Constituição do Estado e tendo em vista o disposto no art. $7^{\circ}$ da Lei Federal no 4.771, de 15 de setembro de 1965,

\section{DECRETA:}

Art. $1^{\circ}$ Fica declarada imune de corte e exploração no Estado de Minas Gerais a leguminosa arbórea conhecida como Faveiro de Wilson, Dimorphandra Wilsonii Rizz, para sua preservação que encontra-se ameaçada de extinção de ocorrência.

Art. $2^{\circ}$ Compete ao Instituto Estadual de Florestas - IEF, aprovar, incentivar e fiscalizar pesquisas científicas sobre a espécie de que trata o art. $1^{\circ}$.

Parágrafo único. Os Núcleos Operacionais de Florestas e Biodiversidade do IEF darão ciência aos Escritórios Regionais e à Diretoria de Desenvolvimento Florestal Sustentável da autarquia, da ocorrência da espécie de que trata este Decreto em outros sítios localizados no Estado.

Art. $3^{\circ}$ Este Decreto entra em vigor na data de sua publicação. 
Diversamente de outros instrumentos legais que possuem basicamente o mesmo intuito preservacionista e que buscam garantir a sobrevivência de espécies da flora, o Decreto mencionado, contudo, inadmitiu, mesmo em situaçóes excepcionais, a supressão da Dimorphandra Wilsonii Rizz.

A Lei Estadual n. 10.883, de 2 de outubro de 1992, que declara de preservação permanente, interesse comum e imune de corte no território do Estado de Minas Gerais o Pequizeiro (Caryocar Brasiliense), previu expressamente em seu artigo $2^{\circ}$ quais as atividades ou situaçôes excepcionais autorizariam sua supressão. Também a Lei Estadual n. 9.743, de 15 de dezembro de 1988, que declara de preservação permanente, interesse comum e imune de corte o Ipê-amarelo, excepcionou, em seu artigo $2^{\circ}$ as situações e atividades que autorizariam a supressão do Ipê.

Igual tratamento, entretanto, não foi dispensado ao Faveiro de Wilson, não se contemplando no texto do Decreto Estadual qualquer atividade ou situação excepcional que ensejasse a supressão de indivíduos da sua espécie.

O Decreto Estadual n. 43.904/04, como se percebe pela leitura de seu cabeçalho, indica como fundamento de sua validade o então vigente Código Florestal - Lei Federal n. 4.771, de 15 de setembro de 1965.

$\mathrm{O}$ artigo $7^{\circ}$ daquele Código dispunha que qualquer "árvore poderá ser declarada imune de corte, mediante ato do Poder Público, por motivo de sua localização, raridade, beleza ou condição de porta-sementes", indicando, conseguintemente, a validade formal do dispositivo inserido no Decreto Estadual.

Dessa forma, sob o ponto de vista formal, o Decreto é válido e erige-se, à primeira vista, como um impeditivo à continuaçáo do licenciamento ambiental no caso analisado, uma vez que para a ampliação da frente de lavra exige-se a supressão dos indivíduos arbóreos cujo decreto protetivo não prevê hipóteses excepcionais para a sua supressáo.

Diante, contudo, das medidas propostas pela empresa requerente no licenciamento ambiental, além dos dados coligidos em seu projeto, que dão conta da baixa expectativa de sobrevida da espécie arbórea, alguns questionamentos poderiam ser feitos: Seria a vedação introduzida no Decreto absoluta? Diante do contexto, da situação fática concreta indicadora de medidas compensatórias, ainda que não encontrassem essas medidas previsão expressa, não haveria possibilidade de supressão 
dos dez indivíduos? A partir de uma filtragem constitucional do citado decreto, seria possível desembaraçar a vedação de cunho, em tese, preservacionista, para pugnar por uma leitura concretizadora do desenvolvimento sustentável?

\section{A (IM)POSSIBILIDADE DE SUPERAÇÃO DA QUESTÃO PELO PARADIGMA DO POSITIVISMO}

Uma análise fria do comando normativo, inserido no artigo $1^{\circ}$ do Decreto Estadual n. 43.904/04, conduziria fatalmente ao indeferimento do pleito de ampliação de lavra aduzido no licenciamento ambiental, uma vez que os dez indivíduos de Dimophandra não poderiam ser suprimidos.

Diferentemente dos outros instrumentos normativos citados que, reconhecendo o caráter de utilidade pública das atividades de mineração (artigo $5^{\circ}$, alínea f, do Decreto-lei n. 3.365, de 21 de junho de 1941) ${ }^{1}$, excepcionalmente permitem a supressão de espécies arbóreas especialmente protegidas, não foram tais atividades contempladas no texto do Decreto objeto do presente estudo.

Dessa forma, poder-se-ia concluir que o desenvolvimento de uma atividade considerada de utilidade pública estaria fadada ao insucesso ante a existência dos dez Faveiros de Wilson? O desenvolvimento sustentável, aduzido nos termos sugeridos no citado relatório Our Common Future (Nosso Futuro Comum) e a partir do qual se extrai a necessidade de compatibilização do exercício regular de uma atividade econômica com a proteção dos recursos naturais, ambos com guarida constitucional, seria inaplicável à situação-problema?

A questão não é de fácil deslinde quando se tem em vista a dogmática jurídica. Imaginar uma soluçáo viável para o caso concreto sem que se tenha de assumir uma posição entre correntes de pensamento distintas, como, por exemplo, a exegético-positivista ou pós-positivista, parece tarefa difícil.

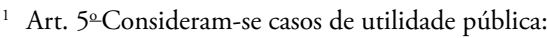

$[\ldots]$

f) o aproveitamento industrial das minas e das jazidas minerais, das águas e da energia hidráulica; 
O professor argentino radicado no Brasil, Luiz Alberto Warat, citado por Lênio Streck (2011), denuncia uma crise de paradigmas a incidir sobre os juristas criando ou perpetuando o que se denominou "senso comum teórico dos juristas". Segundo aquele professor, por meio de standards linguísticos estabelecidos pela opiniâo abalizada de determinada comunidade jurídica, haveria a construção de uma paralinguagem superadora dos significantes e dos sistemas de significação dominantes, deixando prontos para serem absorvidos pelos operadores do Direito, sem muito esforço, palavras, categorias e institutos jurídicos. É o lugar em que a autoridade do argumento cederia espaço, sem reflexão e acriticamente, ao argumento da autoridade.

É preciso, portanto, o desvencilhamento do habitus para se enxergar além e, de forma crítica, buscar uma solução fora do senso comum.

O positivismo exegético ou legalista ${ }^{2}$ conduziria o intérprete do caso concreto forçosamente à aplicação do teor literal do Decreto Estadual. Tal conclusão não seria surpreendente - e a depender da "crença", nem incorreta - quando considerado o habitus fundado e difundido pela Escola da Exegese, ainda hoje presente nas Faculdades de Direito.

A Escola da Exegese, conforme indica Perelman (2004, p. 31), experimentou fases distintas desde sua instauração com a promulgação do Código Civil francês em 1804, alcançando o apogeu em fase posterior, até encontrar seu declínio nos idos de 1889.

Salienta Iara Menezes Lima que, no seio dessa Escola,

[...] o intérprete desenvolve sua atividade totalmente circunscrito ao texto da lei, não lhe sendo dado ir além dele. Realiza apenas um trabalho de exegese, a partir do pressuposto de que a lei contém todo o direito. É um sistema hermético, que pressupõe a plenitude e perfeição da lei escrita, considerada esta com uma revelação completa e acabada do direito (2008, p. 111).

2 Sem que se faça contraposição a um autor ou autores específicos, adota-se, no presente trabalho, como ponto de análise, o positivismo legalista, também denominado de formalismo jurídico, para fins de uma leitura à qual se possa contrapor a tópica, não obstante o conhecimento e desenvolvimento de três outras teses acerca do positivismo (ceticismo ético, positivismo ideológico e positivismo conceitual). Para análise das teses de maneira aprofundada, conferir Introdução à Análise do Direito (2010), do argentino Carlos Santiago Nino. 
A atividade do intérprete, portanto, estaria limitada e orientada à busca da vontade da lei (voluntas legis).

Certamente, a concepção de Direito sustentada pelos defensores da Escola da Exegese, segundo a qual bastaria a subsunção do fato à norma, em típica atitude silogística característica do método das ciências naturais, hoje encontra resistência.

Romper com paradigmas dominantes e arraigados no imaginário dos juristas, a ponto de se constituir um hábito, não é, como se disse, tarefa simples, o que foi muito bem evidenciado por Perelman e Olbrechts-Tyteca (2005), quando introduziram o seu Tratado da argumentação: a nova retórica. ${ }^{3}$

A realidade dos fatos do caso concreto, os delineamentos da hermenêutica tal como proposta por Friedrich Müller e os elementos trazidos pela tópica concretista, somados àqueles elementos já estabelecidos na Teoria do Direito, contudo, fornecem subsídios a uma outra análise do problema que agora se tentará empreender.

\section{A TÓPICA E O SEU DESENVOLVIMENTO}

\subsection{A Tópica em Viehweg}

Theodor Viehweg foi o responsável por resgatar a tópica no âmbito jurídico. Em uma obra aparentemente simples, mas de profundidade singular, colocou o autor todo o seu gênio.

\footnotetext{
3 Na introdução da obra, os autores anotam: "A publicação de um tratado consagrado à argumentação e sua vinculação a uma velha tradição, a da retórica e da dialética gregas, constituem uma ruptura com uma concepção da razão e do raciocínio, oriunda de Descartes, que marcou com seu cunho a filosofia ocidental dos três últimos séculos. Com efeito, conquanto não passe pela cabeça de ninguém negar que o poder de deliberar e de argumentar seja um sinal distintivo do ser racional, faz três séculos que o estudo dos meios de prova utilizados para obter a adesão foi completamente descurado pelos lógicos e teóricos do conhecimento. Esse fato deveu-se ao que há de náo-coercivo nos argumentos que vêm ao apoio de uma tese. A própria natureza da deliberação e da argumentação se opóe à necessidade e à evidência, pois não se delibera quando a solução é necessária e não se argumenta contra a evidência" (Perelman; Olbrechts-Tyteca, 2005, p. 1).
} 
Viehweg relata em sua Tópica e Jurisprudência que a arte da disputa remonta a períodos anteriores à Aristóteles, mas que coube ao Estagirita nominá-la e sistematizá-la em seu Organon com vistas a uma tópica universalizante.

A tópica aristotélica é bastante peculiar, visto que se origina de um proceder típico dos retóricos e sofistas, personagens questionados, pelo seu modus vivendi, por Sócrates e Platão, influentes no pensamento aristotélico.

Aristóteles procura, com o desenvolvimento de sua tópica, promover uma distinção do que é apodítico, pertencente ao campo da verdade e, portanto, pertinente ao âmbito filosófico, em face do que é meramente opinável, dialético, oriundo da prática dos retóricos e sofistas.

Sua tópica não tem em vista o apodítico, mas pretende conferir validade às proposiçôes firmadas com base no meramente opinável, com vistas a uma conclusão que se aproxime da verdade.

A tópica aristotélica reafirma a arte de disputar pretendendo enquadrá-la dentro de sua Ciência da Lógica, esquematizando-a a partir de proposiçóes e da busca por conclusóes aceitáveis, tomando-se por base um catálogo de tópicos auxiliares na decisão (topoi).

Como afirmado, Aristóteles tinha em vista uma tópica universalizante, isto é, um catálogo de opiniōes aplicáveis universalmente e úteis a qualquer tipo de discussão.

A pretensão de Aristóteles não foi partilhada por Cícero que, a partir da obra do mestre grego e com uma finalidade específica de aclarar aquele compêndio ao jurista Trebatius, formulou sua própria versão da tópica. A tópica ciceroniana, segundo registros históricos, foi muito mais notabilizada do que aquela que lhe serviu de suporte, talvez pelo fato de ter menor alcance e de ser mais simples em sua estrutura do que a tópica aristotélica.

Cícero, de fato, preocupava-se com os resultados que poderiam ser colhidos com a tópica e pouca importância emprestou, como relata Viehweg (2008, p. 28), à distinção entre o apodítico e o dialético. 
As divergências, entretanto, entre a tópica aristotélica e a tópica ciceroniana, servem apenas, no contexto da obra de Theodor Viehweg, para desembaraçar o pensamento de Vico e sua tentativa de conciliar o novo e o antigo método.

Viehweg (2008, p. 17) afirma a importância da obra de Gian Battista Vico para o desenvolvimento da Ciência Jurídica ao reconhecer na tópica a estrutura de predomínio na Antiguidade, a partir da qual se desenvolveu a Jurisprudência.

Vico, em sua De nostri temporis studiorum ratione ( $O$ modo de estudar do nosso tempo), citada em Viehweg (2008), buscou a conciliação do método novo, de cariz cartesiano, com o método antigo, retórico (tópica), procurando traçar o percurso deste método desde a Antiguidade, a fim de comprovar sua pertinência no modo de pensar da atualidade.

Viehweg, então, após os esclarecimentos quanto aos precedentes do pensar tópico, sintetiza:

O aspecto mais importante na análise da tópica constitui a constataçáo de que se trata de uma técnica do pensamento que está orientada para o problema. [...] A tópica pretende proporcionar orientaçóes e recomendaçóes sobre o modo como se deve comportar numa determinada situaçấo caso não se queira restar sem esperança. Essa constitui-se, portanto, a técnica do pensar problematicamente (2008, p. 33).

Sobressai da síntese de Viehweg a prevalência do problema, ou em outros termos, a orientação pela qual a ênfase deve recair sobre o problema.

A tópica, enquanto técnica do pensar problemático, que se ocupa e dá ênfase ao problema em prol de uma conclusão apropriada, fundada ou não em um catálogo de tópicos, mereceu análise acurada não somente por Viehweg, mas por toda uma corrente de juristas.

Viehweg, entretanto, esboçou o que, mais tarde, Müller (2010) chamaria de "tópica pura”, em detrimento da tópica desenhada por outros autores, setorizada no âmbito do Direito Constitucional. 
O que se deve destacar no desenvolvimento da tópica de Viehweg, e que no presente artigo interessa, é o fato de a mesma, a partir da retórica, estabelecer-se enquanto técnica de pensar o problema, o caso concreto, afastando-se de um procedimento dedutivo-sistemático, peculiar às ciências naturais, com forte influência sobre o modelo positivista legalista.

Partindo-se de pontos de vistas orientadores, diretivos, porém implícitos, decorrentes de um pensar naturalmente articulado, ou partindo-se de um catálogo repertorizado de pontos de vista, igualmente diretivos (topoi), o que se denominou tópica de primeiro e segundo graus respectivamente, arquiteta-se a tal forma de pensar problematicamente que deve conduzir a uma decisão equânime.

Foi sobre as bases consolidadas por Viehweg que outros autores, sobretudo alemães, como Konrad Hesse, Friedrich Müller e Peter Häberle, puderam, cada qual com sua especificidade, desenvolver a tópica concretista.

\subsection{A Tópica em Müller}

A tópica concretista de Friedrich Müller tem como ponto de partida os lineamentos traçados por Viehweg e, especialmente, as contribuiçóes de Konrad Hesse (2009), ex-juiz do Tribunal Constitucional Federal alemão, que muito se preocupou em garantir que a interpretaçáo (constitucional), entendida como concretização, conduzisse o intérprete-juiz a um resultado correto de fundamentação racional e controlável.

Müller (2010), com a sua obra Metodologia do Direito Constitucional, avança contra o modo de trabalho do positivismo no âmbito do Direito Constitucional, denunciando o fracasso dos métodos de interpretação cunhados por Savigny, salientando que seus cânones não foram pensados para o Direito Constitucional, mas antes para o Direito Civil, âmbito do Direito Privado.

Nesse sentido, o autor assume um projeto audacioso, preocupando-se em estruturar uma metódica para o Direito Constitucional, no bojo da qual a tópica se insere. Assim, explana Müller acerca da metódica que pretende desenvolver: 
A “metódica estruturante" aqui apresentada é desenvolvida com base no e com vistas ao direito constitucional. A denominação "metódica estruturante" resume o que foi dito sobre a estrutura da norma e texto da norma, de normatividade e processo de concretização, sobre o nexo entre concretização estruturada da norma e as tarefas das funçóes individuais da práxis jurídica, sobre a não identidade de norma e texto da norma e sobre a não identidade de concretização e interpretação; resume, outrossim, os enunciados sobre o papel da pré-compreensão, do "sistema", da "axiomática" e da "tópica". A metódica estruturante analisa as questóes da implementação interpretante e concretizante de normas em situaçóes decisórias determinadas pelo caso. Ela apreende a hierarquia igual de elementos do programa da norma e do âmbito da norma. Ela procura desenvolver meios de um trabalho controlável de decisão, fundamentação e representação das funçóes jurídicas (Müller, 2010, p. 68).

Do pequeno excerto que pretende resumir a metódica ${ }^{4}$ mülleriana assomam expressóes e significados fundamentais para a compreensão de sua tese que, em razão da pretensão deste estudo, não poderão ser todas abordadas.

A diferenciação entre texto da norma, norma e normatividade, essenciais a esta proposta de trabalho, porém, merecem uma análise mais próxima. Além disso, ressai também a finalidade primordial da tópica mülleriana em proporcionar um método mais seguro para a construção de decisóes jurídicas.

Como já mencionado, o texto da norma para os adeptos do positivismo representa o limite de seu trabalho exegético, não sendo permitido inquirir-se do direito além daquele limite. Atento a isso, Müller (2010, p. 57) estabelece que o texto da norma e sua literalidade correspondem ao "programa da norma", o que, para o entendimento clássico, representaria o enunciado normativo, a "ordem jurídica”.

\footnotetext{
4 A metódica de Friedrich Müller, como salienta o próprio autor, é tratada como hermenêutica, não referida simplesmente como a técnica retórica aplicada à ciência jurídica, mas, sobretudo, como modalidade de trabalho de concretização de um comando normativo. Vista dessa forma, sob a perspectiva hermenêutica, é de se salientar que a concepção defendida por autores como Müller não abarca a totalidade de concepções e entendimentos sobre a matéria, devendo-se registrar que desde as contribuiçóes de Schleiermacher (1768-1834) a hermenêutica, e de uma forma especial, a hermenêutica jurídica, receberam importantes aportes científicos.
} 
Ao lado do "programa da norma", de seu teor literal, enxerga-se outro componente da estrutura da norma, a saber, o "âmbito da norma". Por este, quer Müller (2010, p. 58) se referir ao "recorte da realidade social na sua estrutura básica, que o programa da norma 'escolheu' para si ou em parte criou para si como seu âmbito de regulamentação."

Adiante esclarece o autor que o âmbito da norma:

[...] é parte integrante material da própria prescrição jurídico $(s i c)$. Da totalidade dos fatos afetados por uma prescrição, do "âmbito material", o programa da norma destaca o âmbito da norma como componente da hipótese legal normativa (normativtatbestand). O domínio da norma é um fator coconstitutivo da normatividade. Ele não é uma soma de fatos, mas um nexo formulado em termos de possibilidade real de elementos estruturais que são destacados da realidade social na perspectiva seletiva e valorativa do programa da norma e estão, em regra, conformados de modo ao menos parcialmente jurídico. Em virtude da sua conformação jurídica e da sua seleção pela perspectiva do programa da norma, o domínio da norma transcende a mera facticidade de um recorte da realidade extrajurídica. Ele não é interpretável no sentido de uma "força normativa do fático". Com isso a norma jurídica prova ser um modelo de ordem materialmente caracterizado (sachgeprägtes Ordnungsmodell), esboço vinculante de um ordenamento parcial da comunidade jurídica que representa o enunciado jurídico em linguagem e na qual os fatores ordenante e ordenando necessariamente formam uma unidade e se complementam e reforçam reciprocamente de forma incondicional na práxis da realização do direito (Müller, 2010, p. 59).

Vê-se que a tríade composta por "programa da norma", "âmbito da norma" e "normatividade" deve ser vista em sua interconexão necessária, porque forma uma unidade reciprocamente considerada na realização prática do Direito.

Isolar-se o "programa da norma" daquele recorte social, desconsiderando-o, é privá-lo de normatividade. Não há, portanto, ordem jurídica ou enunciado normativo isolados daquele substrato material que impele à construçáo de determinado preceito normativo. De igual forma, o recorte social, isoladamente considerado, não reforça ou sobrepóe o fático sobre o normativo.

Müller aduz, com razão, que: 
No âmbito efetivo da concretização prática do direito, "direito" e "realidade" não são grandezas que subsistem autonomamente por si. A ordem (Anordnung) e o que por ela foi ordenado são momentos de concretização da norma, em princípio eficazes no mesmo grau hierárquico, podendo ser distinguidos apenas em termos relativos (2010, p. 59).

Diante de tais assertivas e ante o novo arcabouço conceitual formulado pelo autor, percebe-se que a mera interpretação, com seus recursos e regras, náo pode e não deve ser confundida com a almejada concretização.

A interpretação se prende ao texto da norma. Não que o texto da norma e o seu teor literal não sejam de valia para a hermenêutica mülleriana. Aliás, o próprio autor acentua tal importância e, por diversas vezes, elege o texto da norma como balizador do processo interpretativo.

Ocorre que a concretização ultrapassa a mera interpretação e, sem desconsiderar o texto da norma, ocupa-se de seu âmbito e da normatividade. Não desconsidera “os problemas da 'pré-compreensão' da ciência jurídica e do fato da concretização estar referida ao caso" (Müller, 2010, p. 61-62).

Não é, pois, o teor literal da norma que regulamenta um dado caso concreto, mas a norma e o próprio caso decidendo é que forneceráo os elementos necessários à decisão jurídica, o que, como se verá, integram o pensamento tópico de Müller.

Ao realçar o papel da pré-compreensão no processo de concretização, Müller dá notas de sua adesão aos fundamentos de uma hermenêutica de cariz filosófico, na esteira daquela desenvolvida e propalada por Gadamer (2011).

O desenvolvimento da hermenêutica filosófica, principalmente em Gadamer, volta seu olhar ao fenômeno da compreensão, porém distanciado de um enfoque metodológico ou mesmo com a pretensão de apresentar uma fundamentação última das Ciências do Espírito (Gesteiswissenchaften). Tal hermenêutica quer se voltar para o acontecimento em si da compreensão, na esteira daquilo que Heidegger (2012) empreendeu ao referir-se ao compreender na condição de um existencial.

Nesse sentido, ao esboçar uma metódica do Direito Constitucional, Müller (2010, p. 52) afirma que a "metódica do trabalho é uma metódica de titulares de funçóes. Em nível hierárquico igual ao da jurisprudência e da ciência jurídica, a 
legislação, a administração e o governo trabalham na concretização da constituição.” Com isso ressalta o autor quem são os responsáveis pelo papel fundamental da concretização, esclarecendo a relevância atribuída a outros atores que não apenas aqueles inseridos no Judiciário, o que, para o caso em análise, somente reforça a possibilidade de aplicação da tópica de Müller.

Desenvolvida a teoria para o Direito Constitucional, a metódica de Müller não encontra embaraços para a sua aplicação ao caso de licenciamento ambiental ilustrado na situaçáo-problema, uma vez que, conforme assinalado, trata-se esse de um instrumento garantidor de um direito fundamental previsto na PNMA. A situação-problema analisada no presente trabalho, relativa à possibilidade de manutenção ou extinção de espécies da flora, corresponde diretamente ao direito fundamental de todos ao meio ambiente ecologicamente equilibrado, e a instrumentalizaçáo de tal direito se dá mediante o procedimento administrativo de licenciamento ambiental.

Exalçando o papel fundamental dos titulares de funçôes na concretização da Constituição, amplia o autor o leque de legitimados à interpretação e concretização dos direitos e garantias inseridos nesse documento. Enxergando para além da jurisprudência e da ciência jurídica, possibilita-se à Administraçâo, em sua típica função executiva, a concretização da Constituição.

$\mathrm{Na}$ situação-problema proposta no presente trabalho, o Copam, órgão colegiado de deliberação, tem, portanto, papel crucial no deslinde do problema, porque é o colegiado que realizará a concretização da norma constitucional.

Müller afirma, ainda, com razão, que:

Também os atingidos (betroffenen) que participam da vida política e da vida da constituição desempenham funções efetivas de concretização das normas constitucionais em uma abrangência praticamente não superestimável, ainda que apareçam menos e costumem ser ignorados metodologicamente: por meio da observância da norma, da obediência a ela, de soluçóes de meio termo e arranjo no quadro do que ainda é admissível ou defensável no direito constitucional, e assim por diante. Se a constituição deve desenvolver força normativa, a "vontade à constituiçáa”, que é uma vontade para seguir ou concretizar e atualizar a mesma, não pode permanecer restrita à ciência jurídica enquanto titular da função no 
sentido mais amplo e aos titulares de funções no sentido mais estrito, que foram instituídos, encarregados, legitimados e dotados de competências de decisão e sanção pela constituição e pelo ordenamento jurídico, mediante prescriçôes de competências (2010, p. 53).

O papel de concretização é, portanto, um papel de múltiplos atores, todos envolvidos, na sua medida, com a (pré) compreensão do Direito e com a sua interpretação. Tal enfoque, já bastante distante de velhos paradigmas repetidos no Direito, revela uma nova percepção da Ciência Jurídica.

A metódica mülleriana, como colocada, é audaciosa. E assim o é porque pretende esquadrinhar o processo de formação e fundamentação de uma determinada decisão jurídica, propiciando a quem se dirige a decisão controlá-la, averiguando seu acerto.

Ao estabelecer uma estrutura ordenada de elementos para a concretização, Müller deu um passo largo na superação do positivismo, porém não se manteve infenso a críticas.

Sua teoria não pode e não deve servir de fundamento ao solipsismo do intérprete (seja ele juiz, administrador ou legislador), ao arbítrio ou discricionariedades do sujeito (e do seu subjetivismo) na análise do caso concreto.

\section{A TÓPICA E O CASO CONCRETO}

Na situação-problema relatada no presente estudo e voltando-se a Viehweg, os dados do caso concreto trazidos ao conhecimento do intérprete permitem, naquilo que se denominou tópica de primeiro grau, aferir a incorreçáo ou desacerto de uma decisão que privilegie o teor literal do texto da norma, em detrimento dos demais elementos relacionados na questáo.

Viehweg assim observa:

Naturalmente, se num problema há conflito em alguma parte, pode-se proceder, simplesmente, a se escolher livremente de modo tal a se aferir por meio de tentativas de pontos de vista mais ou menos ocasionais. Deste modo, busca-se 
as premissas que sejam adequadas e profícuas no mérito que permitam levar a consequências idôneas e que apresentem alguma coisa esclarecedora. A observação evidencia que na vida diária quase sempre assim se procede (2008, p. 36).

Embora a tópica de primeiro grau dê bons indicativos de uma conclusão profícua ao caso concreto, sua insegurança, principalmente no campo do Direito, revela sua insuficiência. De toda forma, é interessante observar que esses pontos de vista diretivos de uma decisão em primeiro grau revelam também que o Direito é bom-senso e que dele não se deve (e não se pode) afastar.

Em um procedimento encadeado visando à tópica de segundo grau, ainda com base em Viehweg, a solução deveria ser buscada em um catálogo de pontos de vistas disponíveis. Tal catálogo, quando se aproxima da metódica mülleriana, poderia ser encontrado na procedimentação ou estrutura oferecida em sua tópica concretista:

A concretização da norma introduz os seguintes elementos no jogo:

a) elementos metodológicos "strictiore sensu" (interpretaçóes gramatical, histórica, genética, sistemática e "teleológica", bem como princípios isolados da interpretação da constituiçấo);

b) elementos do âmbito da norma;

c) elementos dogmáticos;

d) elementos de teoria;

e) elementos de técnica de solução e

f) elementos de política do direito e política constitucional.

Os elementos listados em (a) e (b) bem como uma parte dos listados em (c) são diretamente referidos a normas. $\mathrm{O}$ restante dos elementos listados em (c), os elementos listados em (d), (e) e (f) não são diretamente referidos a normas e nessa medida estáo restritos a funçôes auxiliares de concretizaçâo. Uma análise mais precisa dos aspectos individuais, especialmente da interpretação gramatical, histórica, genética, sistemática e "teleológica", bem como dos elementos do âmbito da norma, resulta em numerosas compreensões da estrutura do processo da implementação prática da norma, que vão além do positivismo legalista (Müller, 2010, p. 106). 
Partindo-se dessa estrutura e com vistas à aplicação da tópica concretista de Müller à situação-problema relatada, pode-se afirmar que aos elementos diretamente referidos a normas no presente caso concreto, em especial os aspectos da interpretação sistemática e teleológica, deveráo somar-se aqueles aspectos não diretamente referidos, principalmente os elementos de política do direito.

Não obstante o artigo $1^{\circ}$ do Decreto estadual ora analisado disponha literalmente que a espécie Dimorphandra Wilsonii Rizz é imune de corte e exploração no Estado em razão de encontrar-se ameaçada de extinção de ocorrência, seu artigo $2^{\circ}$, em análise e interpretação sistemática, elemento metodológico strictiore sensu, atribui ao Instituto Estadual de Florestas (IEF) a competência para incentivar pesquisas acerca da espécie.

A finalidade (elemento teleológico strictiore sensu) do mencionado artigo $2^{\circ}$ claramente é propiciar meios e mecanismos de continuidade da espécie o que, indubitavelmente, integra também o âmbito da norma.

Esses apontamentos iniciais que propugnam pela aplicação de elementos strictiore sensu conjuntamente com o âmbito da norma, indicam que, além do caráter preservacionista do Decreto, encontra-se sua finalidade de perpetuação da espécie. Assim não fosse, atingida a expectativa de vida do indivíduo ou se sobre o mesmo se abatesse um evento capaz de matá-lo, a finalidade preservacionista de nada serviria.

Em auxílio aos mencionados elementos diretamente referidos, pode-se ainda recorrer aos elementos de política do direito. Acerca deles, esclarece Müller:

Na pergunta pelas consequências de determinadas variantes de solução, pelos efeitos práticos, e.g., também sobre os âmbitos de normas de outras prescrições e áreas da constituiçáo, não diretamente participantes do caso, no caso do ponto de vista da adequação à finalidade e no das partes da pré-compreensão jurídica que em regra fazem partir os intérpretes da assunçáo de que o legislador teria, com suas prescriçóes, instituído decisóes em princípio conformes à finalidade ou ao menos argumentativamente defensáveis - em todas essas direçóes se faz sentir a peculiaridade da argumentação em política do direito e política da constituição (2010, p. 93). 
Os elementos de política de direito e de direito constitucional, não são, como mencionado, diretamente referidos às normas, e por isso têm caráter meramente auxiliar, o que, com a presente proposta de solução, parece apresentar a melhor decisão para a questão.

\section{CONCLUSÃO}

Enquanto técnica de pensar o problema, a tópica apresenta campo fecundo para a busca de uma solução justa.

Afastando-se de standards jurídicos vistos como "pré-moldados", prontos e acabados, esperando apenas sua utilização na "construção" da decisão jurídica, a tópica concretista aparece com novos elementos, ao lado dos tradicionalmente conhecidos, ofertando a possibilidade de acerto com uma decisão mais justa para o caso concreto.

A realidade não se afasta do Direito, mas nele se entranha, coconstituindo-o. Tal assertiva obriga o jurista a pensar o Direito e agir no Direito de forma diversa, raciocinada e refletida.

A metódica apresentada por Müller e a normatividade das regras de preferência desenvolvidas dentro dessa estrutura, voltadas para o Direito Constitucional, puderam ser testadas no caso concreto porque a matéria ali discutida tinha também guarida constitucional, apontando, assim, para uma estrutura mais próxima não somente do jurisdicionado, mas de todos os que se submetem a uma decisão jurídica.

Na situação-problema relatada na presente abordagem, a tópica concretista ofereceu subsídios a uma decisão do Copam que ultrapassou velhos paradigmas do Direito, possibilitando enxergar-se uma saída para além do mero teor literal de um dispositivo inscrito em um decreto estadual.

A partir da aplicação dos elementos metodológicos strictiore sensu (interpretação teleológica e sistemática) somados aos dados do caso concreto, perpassando o decreto estadual por uma leitura que concilia o desenvolvimento econômico com a 
preservação ambiental (encontradiços na Constituição) e que delineiam, segundo a metódica ora analisada, os elementos de política constitucional, acredita-se ter sido possível buscar uma aplicação prática para a tese mülleriana.

\section{REFERÊNCIAS}

ALMG. Lei Delegada n. 180, publicada em 20 de janeiro de 2011. Disponível em: <http:// www.almg.gov.br/consulte/legislacao >. Acesso em: $1^{\circ}$ mar. 2016 a.

. Decreto estadual n. 45.824, publicado em 20 de dezembro de 2011. Disponível em: <http://www.almg.gov.br/consulte/legislacao . Acesso em: $1^{\circ}$ mar. $2016 \mathrm{~b}$.

BELCHIOR, G. P. N. Hermenêutica jurídica ambiental. São Paulo: Saraiva, 2011.

BELLO FILHO, N. B. Direito ao ambiente: da compreensão dogmáticca do direito fundamental na pós-modernidade. Porto Alegre: Livraria do Advogado, 2012.

BONAVIDES, P. Curso de Direito Constitucional. 15. ed. São Paulo: Malheiros, 2004.

BRASIL, Lei Federal n. 6.938, publicada em 31 de agosto de 1981. Disponível em: <http:// www.planalto.gov.br/ccivil_03/Leis/L6938.htm>. Acesso em: 1º mar. 2016.

. Lei federal n. 4.771, publicada em 15 de setembro de 1965. Disponível em: <http:// www.planalto.gov.br/ccivil_03/leis/L4771.htm>. Acesso em: 1º mar. 2016.

. Constituição da República Federativa do Brasil, promulgada em 5 de outubro de 1988. Disponível em: <http://www.planalto.gov.br/ccivil_03/Constituicao/Constituicao. $\mathrm{htm}>$. Acesso em: $1^{\circ} \mathrm{mar} .2016$.

GADAMER, H.-G. Verdade e método I: traços fundamentais de uma hermenêutica filosófica. Trad. Flávio Paulo Meurer. Revisão da trad. Enio Paulo Giachini. 11. ed. Petrópolis: Vozes, 2011.

HEIDEGGER, M. Ser e tempo. Tradução, organização, nota prévia, anexo e notas Fausto Castilho. Campinas: Editora da Unicamp; Petrópolis: Vozes, 2012.

HESSE, K. Temas fundamentais do Direito Constitucional. Trad. Carlos dos Santos Almeida, Gilmar Ferreira Mendes, Inocêncio Mártires Coelho. São Paulo: Saraiva, 2009.

LIMA, I. M. Escola da Exegese. Revista Brasileira de Estudos Políticos, Belo Horizonte, n. 97, p. 105-122, jan./jun. 2008.

MÜLLER, F. Metodologia do Direito Constitucional. Trad. Peter Naumann. 4. ed. rev. atual e ampl. Sáo Paulo: Revista dos Tribunais, 2010. 
NINO, C.S. Introdução à análise do Direito. Trad. Elza Maria Gasparotto. São Paulo: Martins Fontes, 2010.

PERELMAN, C. Lógica jurídica: nova retórica. Trad. Vergínia K. Pupi. 2. ed. São Paulo: Martins Fontes, 2004.

PERELMAN, C.; OLBRECHTS-TYTECA, L. Tratado da argumentação: a nova retórica. Trad. Maria Ermantina de Almeida Prado Galvão. 2. ed. São Paulo: Martins Fontes. 2005. STRECK, L. Hermenêutica jurídica e $(m)$ crise: uma exploração hermenêutica da construção do Direito. 10. ed. rev. atual e ampl. Porto Alegre: Livraria do Advogado, 2011.

VIEHWEG, Th. Tópica e jurisprudência: uma contribuição à investigação dos fundamentos jurídico-científicos. Trad. Kelly Susane Alflen da Silva. Porto Alegre: Sergio Antonio Fabris, 2008.

Recebido em: 1\%/3/2016

Aceito em: 20/4/2016 